\title{
Doing the individual and the collective in forensic genetics: governance, race and restitution
}

\author{
Amade M'charek ${ }^{1} \cdot$ Peter Wade $^{2}$
}

Published online: 18 June 2020

(C) Springer Nature Limited 2020

Forensic DNA practice is about identification, about establishing the identity of an individual, usually a suspect, a perpetrator or a victim. Yet in order to establish this identity, the individual has to be placed in the context of a population. The contributions in this special issue zoom in on this relation between the individual and the population. Our aim is to attend closely to the kind of work that forensic genetics is made to do; the kind of (legal, political, societal) infrastructures necessary for that work; and the ways it necessarily orders social relations, producing effects of proximity and distance between collectives, while apparently dealing only with the individual. Race — as a particular and highly charged kind of collective category-is a central concern in this special issue, and focusing on the tension between the individual and the collective helps us to broaden its scope and view the different kinds of politics at stake when it becomes entwined in the work of forensic technologies.

In this introduction to the special issue 'Doing the Individual and the Collective in Forensic Genetics: Governance, Race and Restitution' we will first elaborate the relation between the individual and the population in the context of forensic genetics, and address how 'the population' changed from being a problem for DNA evidence in the early nineties to become a category of value for present-day applications. We will explicate the ways in which the valuing of population comes with a resurgence of race through the controversial UK case of the Night Stalker. We will then address other collectives that are valued and mobilised in forensic genetic research, arguing that this is part and parcel of forensic DNA being not solely an identification tool but also increasingly a tool to generate leads during the criminal investigation. Finally, as forensic genetic methods and technologies have nowadays

Amade M'charek

A.A.Mcharek@uva.nl

1 University of Amsterdam, Amsterdam, The Netherlands

2 Department of Social Anthropology, University of Manchester, Manchester M13 9PL, UK 
travelled to disparate fields, we will briefly address their role in migration and border management regimes and the dual processes of control of migrants and restitution through family reunification.

\section{Population: from a problem to a category of value}

As much as it has become a self-evident and a routine practice, forensic DNA has had a turbulent history. When Sir Alec Jeffreys introduced this technology in a family reunion case concerning a Ghanaian family in the UK, its potential for the criminal justice system immediately became clear (Jeffreys et al. 1985). If a DNA profile could help to establish a link between an individual and other members of his family (as was the case for the Ghanaian family), might it also work for the forensic identification of individuals (Gill et al. 1985)? At that time it was crucial that the VNTR and later STR markers were based on non-coding DNA. ${ }^{1}$ Since linking crime to genetics was quite a controversial move to make (Duster 1992, 2003), it was key that forensic genetic research would be based on non-coding DNA as not to reveal any personal information about a suspect of crime. ${ }^{2}$ Another issue was that of contamination and the soundness of technologies and methods used. A number of cases, such as the US New York vs. Castro and the highly mediatised OJ Simpson trials, had demonstrated scientific misconduct, with ensuing heated debates about the efficacy and soundness of the technology and organisation of the forensic work (Jasanoff 1995; Lander 1992). This led to recommendations for the securing, registration and transportation of evidence containing biological traces throughout the process from crime scene to court, and for rigorous protocols to enhance the rapid discovery of contamination or admixture between samples within the laboratory. ${ }^{3}$ But the thorniest issue was that of population, an issue that led to controversy and debate, for example, in 1991 in the popular scientific magazine Science.

What was the problem? Although a DNA profile can potentially individualise and thus help to identify a person, this can only be done when it is compared to a population. This comparison is meant to quantify the likelihood that a particular individual's profile is shared with other people because it is more common in the population to which the individual is thought to belong. In laboratory practice this is done by comparing the DNA profile to a reference population; a population that is deemed statistically representative of the bigger population in question. But what is a representative population (M'charek 2000)? In 1991, Richard Lewontin and Daniel Hartl published a paper in the journal Science indicating that forensic laboratories may not have access to relevant reference populations and that, in the absence

\footnotetext{
1 Variable number tandem repeats and short tandem repeats. On the shift from VNTRs to STRs, see Kahn (2012).

2 This was also an important argument in various legislations; for the Dutch legislation see M'charek (2008) and Toom (2011).

3 For example, the US National Research Council (1996) produced a study with recommendations on this issue. In Europe most forensic laboratories have to be accredited and work according to ISO standards.
} 
thereof, statistical mistakes can occur (Lewontin and Hartl 1991). ${ }^{4}$ Although they made a number of suggestions to handle the so-called population sub-structures and the associated statistical issues, their critique was seen as a potential bomb under the newly introduced forensic DNA technology. Science thus invited Ranajit Chakraborty and Kenneth Kid to publish a 'counter-article' in the same issue. They argued that the problem of population sub-structures could be countered by specific uses of the already available DNA databanks (Chakraborty and Kidd 1991). However, the controversy was further fuelled by the publication of the report DNA Technology in Forensic Science in 1992, under the aegis of the US National Research Council. In the report, the problem of population sub-structures was acknowledged and suggestions, similar to those made by Lewontin and Hartl, were put forward to counter those problems. It would take another couple of years for this controversy to come to a closure. The precondition that one cannot produce an individualising DNA profile without comparison to a representative population had thus caused problems for the forensic community. Meanwhile, forensic DNA has come of age. It has bypassed the problem of the representative population through the size of databases and the availability of ever more genetic markers.

While initially 'population' constituted a threat to the validity of the DNA profile, particularly in cases where the profile does not individualise but rather hints at commonalities within a specific population, it is precisely this latter quality that is gaining interest. Particularly in the absence of a specific suspect, using DNA to help determine in which population s/he might be found could provide leads for the investigating police. Population has thus moved from a problem to a category of value. To demonstrate this investigative use of DNA profiling and the convoluted relation between the individual and the population, we will briefly discuss an exemplary case.

\section{Population and race: the case of the Night Stalker}

This case took place in the south of London between 1992 and 2009. It was a sensational case, involving at least 203 victims of sexual abuse, rape or burglary, mostly elderly women aged between 65 and 90 years. The perpetrator struck in cycles, and often at night, a reason why he came to known as the "Night Stalker". He did not leave fingerprints, but occasionally left DNA in sperm or in skin particles found under the fingernails of his victims. Although all these offences could be linked to a single perpetrator via DNA, despite all efforts, his identity could not be tracked down. In 2006, 14 years later, the help of the American company DNA Print Genomics was called in. This company, since bankrupt, had developed a DNA witness kit that could produce hints about the appearance of the unknown suspect. 'His partial driver's licence photo' was promised. In practice they provided a statement about his sex and a probabilistic account of his genetic geographical descent based

\footnotetext{
${ }^{4}$ For an early controversial case in the US involving an Abenaki Indian victim in Franklin County in Vermont, see Lewontin (1993); and for a Dutch case involving a Turkish suspect, see M'charek (2000).
} 
on Ancestry Informative markers (AIMs) (see e.g. M'charek 2008; Sankar 2012). As a result the 'partial DNA passport photo' of the Night Stalker was as follows: male, with a geographical origin of $82 \%$ Sub-Saharan Africa, 12\% Native American and $6 \%$ European.

Given the specific colonial history of the UK and the effect thereof on post-colonial migration patterns, the profile based on the probabilistic results was squarely translated by the investigating police into the suspect was a black Caribbean man. ${ }^{5}$ The police reports stated that advanced DNA techniques were used and that they indicated that the suspect probably had Afro-Caribbean ethnicity, probably from the Windward Islands. But what were these 'advanced DNA techniques'? They entailed the enrolment of hundreds of police officers with a Caribbean background, who were more or less forced to give DNA so as to optimise the utility of the DNA witness kit. Since the kit was produced in the US it was not representative of the UK population. The 'advanced technologies' allowed the forensic geneticists to conclude that the suspect probably originated from the Windward Islands. In practice this meant that 21,500 men would fit the profile and that thousands of men residing in London neighbourhoods with large populations of Caribbean background were asked to donate DNA (Johnston 2006). Men who refused to cooperate were threatened and pressured to do so (Greenwood 2009). Four years later, a suspect was arrested. Delroy Easton Grant turned out to be a Londoner with Jamaican background. He was not found based on the DNA profile. His car was spotted on CCTV images at an ATM where he withdrew money from the bank account of one of his victims.

This example makes clear that in the absence of a suspect, individualising DNA is not very helpful. It is rather the collective, to which the unknown suspect is deemed to belong, that becomes relevant in the criminal investigation. However, race and racism are never far away when using this technology. Not only did the probabilistic estimation of geographical descent lead to the 'responsibilisation' of a specific collective within the UK police force in order to be able to deliver an 'advanced DNA technology' for this case, it also incriminated and racialised a large number of innocent citizens. The translation of African descent, through a colonial legacy, into a black Caribbean man, together with the profiling of a specific group of people, did not simply produce a collective, but a racialised collective. This is one of our main concerns in addressing the relation between the individual and the collective in this special issue.

\section{The tension between the individual and the collective}

All the authors in this special issue explore in depth the relation between the individual and the collective in forensic genetics and forensics more widely. They attend to it as a constant tension or "resonance" (Hopman and M'charek 2020, this issue). To be sure, this tension in the specific context of forensic genetics has been noted before (Kahn 2012; M'charek 2000, 2008; Schwartz-Marín et al. 2015). But in this

${ }_{5}^{5}$ For a similar move in a Dutch forensic case, see (Jong and M'charek 2018). 
special issue, the authors make it a key focus of their analysis, showing how the individual and the collective are not opposed, but immanent in each other and in a relation of mutual constitution, producing ambivalent moral and political affordances. All authors are particularly keen on unravelling the category of population and seeing how it is entrained by apparently individualising technologies and procedures. While solving crime and catching a dangerous murderer is, prima facie, a good thing, the collective category 'population of interest' can be dangerous and may easily spill over into 'suspect population' (Cole and Lynch 2006) or even 'criminals' (M'charek et al. 2020). Moreover, as shown above and demonstrated in the contributions of Simon Cole and David Skinner and that of Roos Hopman and Amade M'charek, in practices of crime investigation, population is easily racialised.

In this issue, our contributors cover diverse themes that, however, fit into a simple but handy classification of fields in which forensic genetics and forensics more widely operate. On one side of the spectrum, these technologies are put to work in matters of governance, policing, control, regulation and surveillance, often raising issues of discrimination. Themes that have been studied in the literature include the architecture of DNA databases, what goes into them and how this is regulated, how DNA databases can be used by the state and the private sector for these purposes, and how data can creep and bleed into other databases and functions; privacy, democratic transparency and accountability; and questions of evidence and expertisehow DNA came to be seen as authoritative in forensics, criminal investigation and crime management, and how it operates in practice (Cho and Sankar 2004; Heinemann et al. 2012; Hindmarsh and Prainsack 2010; Lynch and Jasanoff 1998; Toom 2010; Skinner and Wienroth 2019). Included in this area is the way forensic genetics may provide mechanisms to discriminate against racialised categories and, in so doing, rematerialise and authorise 'race' itself in diverse forms (genetic, phenotypic, cultural) (Chow-White and Duster 2011; Fullwiley 2011; Kahn 2012; M'charek 2008; Smay and Armelagos 2000).

On the other side of spectrum, forensic technologies also deployed as tools in matters of restitution, reconciliation, care, and the search for justice and citizen and human rights. Researchers have addressed the role of forensics in identifying individuals in cases of massacres, human rights abuses and disappearances, reuniting body remains with relatives, and providing evidence for associated claims by citizens against the state (and agents seen as its proxies) for abuse and/or negligence (Penchaszadeh 2011; Rosenblatt 2015; Schwartz-Marín and Cruz-Santiago 2016; Smith 2013; Wagner 2008). Included here are instances in which data from DNA ancestry testing may be involved in support of legal claims by racialised and ethnic groups for access to resources (reparations, land, group membership, legal state recognition) (Hamilton 2012). This going together of 'nativism' and biological/genetic identities may contribute to the naturalisation of collective identities and the 'rematerialisation' of race (M'charek et al. 2014).

The contributions to this special issue can be distinguished in terms of these two broad domains of concern, but they also indicate some overlap between them, suggesting there is a continuum at work. The articles by Cole, Skinner, Hopman and M'charek, and Vailly and Bouagga all focus squarely on the use of forensics in the criminal justice system and its use in solving crime. Nevertheless, we can 
see-particularly in the article by Vailly and Bouagga - that these uses give rise to reactions that, engaging with the technologies themselves, attempt to protect citizens from perceived infringements on privacy and rights. The articles by Tapaninen and Helèn, and Smith and García-Deister focus on the use of forensics in contexts of migration, where, while there is a concern with reuniting families, protecting immigrants who lack the expected forms of documentation, and repatriating the remains of dead people to their 'proper' locations, there are also clearly strong elements of governance, control and the policing of national boundaries. In all cases, the collectives (re)produced by the forensic focus on the individual suspect, criminal, immigrant or dead body also involve processes of racialisation, which work to reproduce and reconfigure the racial categories operating in that context.

\section{Forensics in crime solving}

The way forensic technologies operate in the investigation of crime often show some common elements. First, apparently individualising techniques invoke collective categories (often racialised), which can also be used in reverse, i.e. to profile an unknown individual. Second, the way these collectives are defined is based on self or official classifications and this reveals the inherently problematic, but very common, process by which samples of individuals are initially defined in terms of social categories (e.g. white, black, Caribbean, European, etc.), the individuals are then clustered according to their genetic/physical profile (e.g. the frequencies of certain markers), and finally that genetic profile is used to describe the social category in 'real' (i.e. genetically validated) terms. This involves a particular relation between collective and individual: the social and biological are aligned collectively (i.e. the genetic profile drawn from a sample of individuals is taken as a description of the whole social category they were chosen to represent); then individuals are judged in terms of that collective alignment (i.e. any individual identified as belonging to that social category will have that genetic profile), when the social collective was based on a certain sample of individual identifications to start with.

This circular process emerges clearly in the contribution by Simon Cole (2018, this issue). He compares three different forensic technologies, from the classical fingerprint identification, through hair microscopy to microbiome forensics and demonstrates that, despite the aim of identifying an individual suspect, each of these technologies strikes a balance, in different ways, between the individual and the population. While the success of fingerprint identification is due to its capacity to individualise, therewith establishing what Cole calls a template and revering individualised identification as the telos of forensic technologies, microscopic hair analysis is valued not because it individualises (which it cannot effectively do) but rather because it helps to cluster individuals into collective categories, such as 'black' or 'Mexican'. By contrast, microbiome forensics challenges the whole idea of an individual as a person's microbiomes are constantly changing through space and time. However, this unruly variation can be tamed through using the collective as a value. Gender, race and family function as classifications through which the microbiome is made relevant for forensic use. 
David Skinner (2018, this issue) looks at the movement between the individual and collective involved in DNA databases used for policing purposes, when these include data on racial identity, raising issues of the over-representation of racialised minorities that are targeted by the police in the first place and which are then targeted again - now with the backing of statistics-because they are over-represented as criminals and suspects in the database. Drawing on the case of the national DNA police database in the UK, Skinner argues that, with the increasing salience of forensic racial phenotyping and the use of forensic visual technologies that depend on a racial-visual logic, the social and ethical implications of database usage and racial phenotyping of suspects become particularly thorny. Attempts to critique racialisation in phenotyping on ontological grounds, as bad science or biological determinism, miss the ways in which the contemporary race object can encompass corporeal, digital and discursive elements. Skinner also contends that some of the standard ELSI discourse about the invasion of privacy and infringement of rights aligns with a view of racism as series of (aberrant) individual acts; this neglects the operation of structural processes of racism that create the collective disadvantage that means young black men are over-represented in the database.

Vailly and Bouagga (2019, this issue) are also interested in the individual-collective dynamic as it is enacted in databases. The article explores the ethical and political problems with the French DNA profile database identified by its opponents and critics, who draw on national traditions of Republican individualism and privacy to contest what they see as a creeping encroachment of surveillance and related forms of governance. First, the database creates a collective category of 'suspect', which is disproportionate to any real or suspected offences (offences often seen by database critics as in reality political actions of protest linked to an ethical project of citizenship). Second, this collective category includes family members of suspects and criminals, who may be wholly innocent; and it includes a new category created by legislation linked to the database, consisting of people convicted only of the offence that they refused to give a DNA sample when they were first arrested (but not necessarily convicted). A different aspect of the collectivity produced by the database is the fact that DNA profiles using supposedly non-coding markers (which are the only ones allowed under French law) may in fact be usable to generate knowledge about medical conditions and geographical or 'ethnic' origins. Even if the database is never actually used for this purpose (which is technically illegal), critics point to unknown possible abuses in the future, and make comparisons to historical abuses of paper-based databases in Vichy France.

Hopman and M'charek (2020, this issue) complexify the dynamics between the individual and the collective by unpacking the emerging forensic technology of DNA phenotyping. This technology, aimed at giving a face to an unknown individual, usually an unknown suspect, based solely on DNA, is not one unified technology but currently consists of three technological practices that produce different versions of the face and thus different relations between the individual and the collective. Hopman and M'charek provide an ethnographic analysis demonstrating how the focus on pigmentary traits produces a probabilistic rendition of the face, the focus on facial features contributes to a metrically rendered face, while a focus on genetic ancestry contributes to a geographically ordered face. These different 
approaches to the face all aspire to produce individuality, yet all necessarily also produce the collective. This prompts the question: when and where does the collective shift into race? Since the different approaches to the face have a long and racialised history, this article examines how this history is folded into present-day knowledge and so contributes to the racialisation of probabilistic categories of the collective. Hopman and M'charek show that race surfaces both in the laboratories and beyond them when forensic results travel to the police and become part of the criminal investigation.

\section{Forensics, migration and restitution}

Turning now to the articles that focus on the processes of restitution that can sit alongside those of discipline and control, Tapaninen and Helén (2019, this issue) explore the use of DNA and other non-genetic types of evidence adduced in family reunification procedures involving immigrant families in Finland, introducing the theme of the family as a collective. They show that although DNA is valued as a definitive proof of relatedness-including by immigrants whose dependents sometimes lack official papers-it does not displace other kinds of evidence, such as narratives that draw on concepts of how an individual may be seen by immigrants as legitimately related to the collective family unit in non-genetic ways (for example, by adoption, whether formal or informal, and relations created by processes of caring). However, the use of DNA is double-edged and is also deployed to keep out some immigrants when genetic ties do not exist and their narratives about being a legitimate but non-genetic part of the family are not believed by immigration officers. This scepticism is nurtured by the presence of another collective, 'Somalis', whose family structures the officers are dubious about and find hard to read. In this sense, Tapaninen and Helén reinforce the statement made by Smith and GarcíaDeister (this volume): "although individuation is the key goal of forensic science, collective identities, including race, class, gender, and nationality, become obligatory passage points in the path towards individuation".

Smith and García-Deister (2019, this issue) themselves focus on how, in the Mexico-US borderlands, living bodies are seen as threats and are restricted in their movement, while dead body remains (including tissue and DNA samples) become a site of value for science and governance and cross the border quite easily and safely in scientific exchanges. The return of bodies and body parts in the name of family reunification and care involves ultimately identifying the family of a person, using DNA (or sometimes fingerprints). But because of lack of resources and sufficient DNA data, this goal is rarely accomplished and, in the meantime, the focus is on forensically determining the 'correct' national location for the body. Locating the nationality of unidentified dead bodies raises tricky questions-was the person an undocumented Mexican migrant who died north of the border or a homeless US Mexican-American citizen? The process of determining nationality involves negotiations between multiple forms of bureaucratic and scientific data and knowledge, to determine who the person was, where the body belongs, and who has the scientific authority to speak and to act in this respect. In the process, identifying an 
individual body as a Mexican or US citizen effectively reinforces not only already tenacious collective categories, such as nation, but also race. Not surprisingly this is all framed by assertions of state power insofar as both Mexico and the United States are intent on exercising sovereignty over their borders and this entails being able to assign individual dead bodies to specific nation-states-i.e. "necro-sovereignty".

\section{Conclusion}

The papers in this special issue work on the assumption that the individual and the collective are always in a relational flux (M'charek 2000). Forensic genetics is, in one sense, all about identifying the unique individual and locating him or her in time and place. In another sense, however, a collective classificatory dimension is always involved: individuals are often considered as members of a categorygender, of course, but also national, racial or ethnic, a population (M'charek 2000, 2008; Schwartz-Marín et al. 2015). As described earlier on, forensic DNA matching is always carried out in relation to a reference population; as the articles in this special issue show, DNA identifications for policing and other forensic purposes often make reference to the racialised identity of a suspect, as forensic practice in the past also did.

The individualised dimension evokes what Deleuze (1990) called a "society of control", where governance (and business) relies on constant, real-time monitoring of the modulations of masses, consisting not of individuals, but dividuals; assembled profiles (assemblage individuals, one could say) that are registered through CCTV, biometrics, loyalty cards, cookies, etc., which all generate 'big data' in which computer software and AI algorithms can identify patterns or risky behaviour (Ruppert 2009). The collective dimension recalls what Deleuze calls Foucauldian "disciplinary societies", in which individuals are classified into categories, using census-like counting techniques; the categories are then bounded and policed as such. The tension between the individual and the collective is more general and, for example, not dissimilar from that observed in 'personalised' genetic medicine (Prainsack 2015), which in practice targets individuals as members of a category sharing a given trait, who can be targeted with a relevant drug, such as BiDil (Kahn 2013).

The tense but mutually constitutive relationship between the individual and the collective can be understood as an indication of the way different modes of powerDeleuzean control and Foucauldian discipline-combine in today's society, as Foucault himself was well aware (Foucault 2007). We have known for some time that the apparent potential of genomics to dismantle racial categories by virtue of its combination of intense individualisation (everyone is unique) and intense collectivisation (we are all the same) is countered by the powerful tendencies in the same genomic science to work with collective categories in between these two levels of intensity, such as race, nation, ethnicity, etc. (e.g. Wade et al. 2014, 2015). Data at the individual level (or sub-individual in the sense of a specific aspect of a person's behaviour or specific DNA markers) get moulded by algorithms and biostatistical software into collective patterns, such as profiles of consumption preferences, work habits and health risks or geographical groupings. These patterns can be used 
in projects of control and discipline that often reproduce familiar collective categories of race, nation, class and gender, which underwrite the structure of modernity within which science is located.

Acknowledgements This special issue has a long genealogy. Most papers were given a first outing in two workshops on 'Doing the Individual and the Collective in Forensic Genetics: Governance, Race and Restitution' held in September 2016 in Manchester, and May 2018 in Amsterdam. We are grateful to our authors for walking along with us and following the path of this volume. We are also grateful to the funders of the workshops: The British Academy for the workshop in Manchester and the European Research Council for the workshop in Amsterdam. We are most grateful to Filippa Lentzos for excellent editorial guidance. Finally, Amade M'charek thanks the European Research Council for supporting her research through an ERC Consolidator Grant (FP7-617451-RaceFaceID-Race Matter: On the Absent Presence of Race in Forensic Identification); and Peter Wade thanks the British Academy for supporting his research with a Wolfson Research Professorship.

\section{References}

Chakraborty, R., and K.K. Kidd. 1991. The utility of DNA typing in forensic work. Science 254 (5039): 1735-1739.

Cho, M.K., and P. Sankar. 2004. Forensic genetics and ethical, legal and social implications beyond the clinic. Nature Genetics 36 (11): S8-S12.

Chow-White, P.A., and T. Duster. 2011. Do health and forensic DNA databases increase racial disparities? PLoS Medicine 8 (10): e1001100.

Cole, S.A. 2018. Individual and collective identification in contemporary forensics. BioSocieties. https:// doi.org/10.1057/s41292-018-0142-z.

Cole, S., and M. Lynch. 2006. The social and legal construction of suspects. Annual Review of Law and Social Science 2: 39-60.

Deleuze, G. 1990. Society of control. L'autre journal 1: 177-182.

Duster, T. 1992. Genetics, race, and crime: Recurring seduction to a false precision. In DNA on trial: Genetic identification and criminal justice, ed. P.R. Billings, 129-141. Cold Spring Harbor, NY: Cold Spring Harbor Laboratory Press.

Duster, T. 2003. Backdoor to eugenics, 2nd ed. London: Routledge.

Foucault, M. 2007. Security, territory, population: Lectures at the College de France, 1977-78. Basingstoke: Palgrave Macmillan.

Fullwiley, D. 2011. Can DNA "witness" race? Forensic uses of an imperfect ancestry testing technology. In Race and the genetic revolution: Science, myth, and culture, ed. S. Krimsky and K. Sloan, 116-126. New York: Columbia University Press.

Gill, P., A.J. Jeffreys, and D.J. Werrett. 1985. Forensic application of DNA 'fingerprints'. Nature 318 (6046): 577-579.

Greenwood, Chris. 2009. 2,000 DNA tests in hunt for 'night stalker. Independent at https://www.indep endent.co.uk/news/uk/crime/2000-dna-tests-in-huntfor-night-stalker-1816140.html (accessed 29 April 2020).

Hamilton, J.A. 2012. The case of the genetic ancestor. In Genetics and the unsettled past: The collision of DNA, race, and history, ed. K. Wailoo, A. Nelson, and C. Lee, 266-278. New Brunswick, NJ: Rutgers University Press.

Heinemann, T., T. Lemke, and B. Prainsack. 2012. Risky profiles: Societal dimensions of forensic uses of DNA profiling technologies. New Genetics and Society 31 (3): 249-258.

Hindmarsh, R., and B. Prainsack (eds.). 2010. Genetic suspects: Global governance of forensic DNA profiling and databasing. Cambridge: Cambridge University Press.

Hopman R, and A. M'charek. 2020. Facing the unknown suspect: Forensic DNA phenotyping and the oscillation between the individual and the collective. BioSocieties. https://doi.org/10.1057/s4129 2-020-00190-9.

Jasanoff, S. 1995. Science at the bar: Law, science, and technology in America. Cambridge, MA: Harvard University Press. 
Jeffreys, A.J., J.F.Y. Brookfield, and R. Semeonoff. 1985. Positive identification of an immigration testcase using human DNA fingerprints. Nature 317 (6040): 818-819.

Johnston, D. 2006. The Use of DNA in Operation Minstead. Metropolitan Police Authority. September 7, 2006.

Jong, L., and A. M'charek. 2018. The high-profile case as 'fire object': Following the Marianne Vaatstra murder case through the media. Crime, Media, Culture 14 (3): 347-363.

Kahn, J. 2012. Forensic DNA and the inertial power of race in American legal practice. In Genetics and the unsettled past: The collision of DNA, race, and history, ed. K. Wailoo, A. Nelson, and C. Lee, 114-142. New Brunswick, NJ: Rutgers University Press.

Kahn, J. 2013. Race in a bottle: the story of BiDil and racialized medicine in a post-genomic age. New York: Columbia University Press.

Lander, E. 1992. DNA fingerprinting: Science, law, and the ultimate identifier. In The code of codes: Scientific and social issues in the Human Genome Project, ed. D.J. Kevles and L. Hood, 191-210. Cambridge, MA: Harvard University Press.

Lewontin, R.C. 1993. Biology as ideology: The doctrine of DNA. New York, N.Y.: HarperPerennial.

Lewontin, R.C., and D.L. Hartl. 1991. Population genetics in forensic DNA typing. Science 254 (5039): 1745-1750.

Lynch, M., and S. Jasanoff. 1998. Contested identities: Science, law and forensic practice. Social Studies of Science 28 (5-6): 675-686.

M'charek, A. 2000. Technologies of population: Forensic DNA testing practices and the making of differences and similarities. Configurations 8 (1): 121-158.

M'charek, A. 2008. Silent witness, articulate collective: DNA evidence and the inference of visible traits. Bioethics 22 (9): 519-528.

M'charek, A., K. Schramm, and D. Skinner. 2014. Topologies of race: Doing territory, population and identity in Europe. Science, Technology \& Human Values 39 (4): 468-487.

M'charek, A., V. Toom, and L. Jong. 2020. The trouble with race in forensic identification. Science, Technology, \& Human Values. https://doi.org/10.1177/0162243919899467.

National Research Council. 1996. The evaluation of forensic DNA evidence. Washington, DC: The National Academies Press.

Penchaszadeh, V.B. 2011. Forced disappearance and suppression of identity of children in Argentina: Experiences in genetic identification. In Racial identities, genetic ancestry, and health in South America: Argentina, Brazil, Colombia, and Uruguay, ed. S. Gibbon, R.V. Santos, and M. Sans, 213-243. New York: Palgrave Macmillan.

Prainsack, B. 2015. Is personalized medicine different? (Reinscription: The sequel) A response to Troy Duster. The British Journal of Sociology 66 (1): 28-35.

Rosenblatt, A. 2015. Digging for the disappeared: Forensic science after atrocity. Stanford: Stanford University Press.

Ruppert, E. 2009. Making populations: From censuses to metrics. In Sichtbarkeitsregime: Überwachung, Sicherheit und Privatheit im 21 Jahrhundert (Visibility regimes: Monitoring, security and privacy in the 21st century), ed. L. Hempel, S. Krasmann, and U. Bröckling, 157-173. Wiesbaden: VS Verlag.

Sankar, P. 2012. Forensic DNA phenotyping: Continuity and change in the history of race, genetics, and policing. In Genetics and the unsettled past: The collision of DNA, race, and history, ed. K. Wailoo, A. Nelson, and C. Lee, 104-113. New Brunswick, NJ: Rutgers University Press.

Schwartz-Marín, E., and A. Cruz-Santiago. 2016. Forensic civism: Articulating science, DNA and kinship in contemporary Mexico and Colombia. Human Remains and Violence: An Interdisciplinary Journal 2 (1): 58-74.

Schwartz-Marín, E., P. Wade, A. Cruz-Santiago, et al. 2015. Colombian forensic genetics as a form of public science: The role of race, nation and common sense in the stabilization of DNA populations. Social Studies of Science 45 (6): 862-885.

Skinner, D. 2018. Forensic genetics and the prediction of race: What is the problem? BioSocieties. https ://doi.org/10.1057/s41292-018-0141-0.

Skinner D, Wienroth M (2019) Was this an ending? The destruction of samples and deletion of records from the UK police national DNA database. British Journal for the History of Science. 4:99-121

Smay, D.B., and G.J. Armelagos. 2000. Galileo wept: A critical assessment of the use of race in forensic anthropology. Transforming Anthropology 9 (2): 19-40.

Smith, L. 2013. "Genetics is a study in faith": Forensic DNA, kinship analysis, and the ethics of care in post-conflict Latin America. Scholar \& Feminist Online 11 (3): 221. 
Smith, L.A., and V. García-Deister. 2019. Migrant flows and necro-sovereignty: The itineraries of bodies, samples, and data across the US-Mexico borderlands. BioSocieties. https://doi.org/10.1057/s4129 2-019-00166-4.

Tapaninen A-M, Helén I (2019) Making up families: How DNA analysis does/does not verify relatedness in family reunification in Finland. BioSocieties. https://doi.org/10.1057/s41292-019-00148-6.

Toom, V. 2010. Producing suspects. The politics of the national DNA database of England and Wales. Science as Culture 19 (3): 387-391.

Toom, V. 2011. Dragers van Waarheid. Twintig jaar forensisch DNA-onderzoek in Nederland [Carriers of truth. Twenty years of forensic DNA profiling in the Netherlands]. Deventer: Kluwer.

Vailly, J., and Y. Bouagga. 2019. Opposition to the forensic use of DNA in France: The jurisdiction and veridiction effects. BioSocieties. https://doi.org/10.1057/s41292-019-00150-y.

Wade, P., C. López Beltrán, E. Restrepo, et al. (eds.). 2014. Mestizo genomics: Race mixture, nation, and science in Latin America. Durham NC: Duke University Press.

Wade, P., C. López Beltrán, E. Restrepo, et al. 2015. Genomic research, publics and experts in Latin America: Nation, race and body. Social Studies of Science 45 (6): 775-796.

Wagner, S. 2008. To know where he lies: DNA technology and the search for Srebrenica's missing. Berkeley, CA: University of California Press.

Publisher's Note Springer Nature remains neutral with regard to jurisdictional claims in published maps and institutional affiliations.

Amade M'charek is Professor of Anthropology of Science at the Department of Anthropology, University of Amsterdam. She is the PI of the RaceFaceID project, an ERC-consolidator project on forensic identification and the making of face and race. She has a longstanding research interest in genetic diversity, population genetics and forensic DNA practices and in the ir/relevance of race in such practice.

Peter Wade is Professor of Social Anthropology at the University of Manchester. His recent publications include Mestizo Genomics: Race Mixture, Nation, and Science in Latin America (Duke University Press, 2014), and Degrees of Mixture, Degrees of Freedom: Genomics, Multiculturalism and Race in Latin America (Duke University Press, 2017). He has codirected a project on "Latin American Antiracism in a 'Post-Racial' Age" (2017-19) and is directing a project on "Cultures of Anti-Racism in Latin America” (2020-23). 